\title{
Estimation of Prevalence of Food Insecurity in Sri Lanka
}

\author{
Geetha Mayadunne* and K.Romeshun \\ Centre for Poverty Analysis, 29, Gregory's Road, Colombo 7, Sri Lanka. \\ Corresponding Author (Email: geetham@cepa.lk)
}

Received: 04 March 2013 / Revised: 17 June 2013

\begin{abstract}
Information on populations that are food insecure at national and regional level, and changes in food security over time, are important in formulating policy and development interventions for food security. Sri Lankas's food security assessments have been based on composite indices constructed using variables that are direct or indirect determinants of food security. Such composite indices help compare relative food insecurity across geographic areas, and over time, but limit the assessment of the magnitude of the prevalence food insecurity. In this study using deprivation of food energy intake as an indicator of food insecurity, prevalence of food insecurity is measured as the food insecure proportion of populations in specific geographic areas at specific points in time. The probability density function of per capita food dietary energy intake is assumed to follow a lognormal distribution and prevalence of food insecurity is estimated as the proportion of the population whose per capita dietary energy intake per day is unsatisfied in relation to a recommended minimum level. The method was applied to primary data from the National Household Income and Expenditure Surveys conducted in the years 2006-2007 and 2009-2010. The derived food insecurity estimates were validated comparing with official estimates of expenditure poverty, nutritional outcomes and also with the findings from food security assessments based on composite indices, available in the literature. The analysis of prevalence estimates reveal insights on regional differences in food insecurity and changes over time, yielding important implications for policy.
\end{abstract}

Keywords: food insecurity, dietary energy, minimum dietary energy requirement, lognormal distribution

\section{Introduction}

Information on prevalence of food insecurity, measured as population proportions or counts, at country or at regional level and changes over time, are important in formulating food security focused economic and social policies and development interventions . Literature shows that assessments of food insecurity in Sri Lanka (e.g. Food and Agriculture Organization 1983, Wickramasinghe 2009, World Food 
Program 2002, 2006) have been based on composite indices constructed using aggregate $^{1}$ variables falling under the broad dimensions-food availability, economic and physical accessibility which are direct or indirect determinants of food security. Such composite indices help spatial and inter temporal comparisons of 'relative' food security or insecurity, but does not provide estimates of the magnitudes of food insecure populations at a given area at a given point in time. In addition, composite indices carry limitations resulting from choice of variables, statistical aggregation and other issues (De Silva, 2007) inherent to multidimensional composite indices.

Unavailability of proportions or counts of food insecure populations for regions limit formulation of food security focused regional policies and interventions and more importantly the monitoring and evaluation of impacts. In Sri Lanka, with the exception of the food insecurity prevalence estimates at country level (Sri Lanka) ${ }^{2}$ constructed by the Food and Agriculture Organization (FAO 2010, 2012), estimates of proportions or counts of food insecure individuals in different geographic regions, at different points in time are not available. Therefore in this paper we estimate food insecure population proportions at District level by applying a method available in the international literature (Sibrian 2007) using Sri Lanka's Household Income and Expenditure Survey data collected in two different time periods 20062007 and 2009-2010. The reliability of the estimates are validated through comparisons with Sri Lanka's official estimates of, District average food energy intake, expenditure poverty and nutritional outcomes, and are also compared with food insecurity assessments based on composite indices available in the literature (e.g. Food and Agriculture Organization 1983, Wickramasinghe 2009, World Food Program 2002, 2006).

In line with the definitions in the literature (e.g. FAO 2010, 2012 and Sibrian 2007) in this study an individual is defined food insecure if the individual's food energy intake is below a nutritionally recommended minimum level. The basic premise underlying the use of food energy intake as a food insecurity indicator is that a human being is considered undernourished and hence food insecure if the level of his or her habitual dietary energy intake is below the minimum level nutritionists deem appropriate (FAO 2012). The definition on food security used in the Declaration of the World Summit on Food Security (FAO 2009) implies that food security is very much a multidimensional phenomenon, with the final outcome being an adequate intake of food energy and nutrients. With regard to adequacy of nutrients, literature (Naiken 2003, Nanayakkara and Premaratne 1987, Nanayakkara 1994) supports that food giving the required dietary energy bring with it proteins and other nutrients as well, and hence justifies focus on the energy intake.

Based on the work of Sibrian (2007), the probability density function of per capita

\footnotetext{
${ }^{1}$ Aggregated at regional (e.g. District) level

2 Proportion of undernourished measured as the proportion of population whose dietary energy intake is below a minimum dietary energy leve.
} 
dietary energy consumption is assumed to follow a lognormal distribution and prevalence of food insecurity is estimated as the proportion of the population whose per capita minimum dietary energy requirement per day is unsatisfied in relation to a recommended minimum level. The method was applied to primary data on household level food consumption and income, collected by the National Household Income and Expenditure Surveys (HIES) conducted in 2006-2007 and 2009-2010 periods, by the Department of Census and Statistics, Sri Lanka (DCS).

The next sections (1.1-1.3) review selected literature on definitions of food and nutrition insecurity, studies on food insecurity in Sri Lanka, and methods that have been use to assess prevalence of food insecurity. Section 3 explains the methodology; section 4 gives the estimates obtained applying the method to data collected in the 2006-2007 HIES and 2009-2010 HIES and the analysis of estimates. The final section gives the conclusions and recommendations.

\subsection{Definition of food and nutrition insecurity}

Definition of food insecurity is a key concern in measuring food insecurity. Up to the 1970s, food security was seen from a supply side perspective, as stability of food supplies to sustain expansion of food consumption. By the 1980s the perspective was broadened to include physical and economic access by all people to available supplies, implying focus on both demand and supply sides of food security (FAO 1983). In the 1990s the FAO further broadened the definition to incorporate nutrition, food safety, and social preferences (FAO 1996). The State of Food Insecurity in the World 2001 (FAO 2002b) adopted the definition: "Food security is a situation that exists when all people, at all times, have economic, physical and social access to sufficient, safe and nutritious food that meets their dietary needs and food preferences for an active and healthy life.

Some literature (FAO 2002a) view, food insecurity to be conceptualized as a phenomenon which needs consideration of hunger and the risk of future hunger. Hunger and Food insecurity are distinct but complimentary concepts; hunger is an indicator of possible consequences of food insecurity, but the sensation of hunger diminishes with consuming less than necessary over a long period of time and hence subjective articulations of hunger by individuals could be inaccurate; therefore objective indicators such as calorie consumption and consumption of proteins, fats, and micronutrients are likely to capture food insecurity more accurately (Saxena 2008). Naiken (2003) explaining the FAO measure of prevalence of undernourishment measured in terms of food energy intake, states that food giving the required dietary energy bring with it proteins and other nutrients as well, and hence justified focus on the energy intake.

\subsection{Review of selected food security studies in Sri Lanka}

Food security studies in Sri Lanka have been based on the multidimensional premise of food security focusing on determinants of food insecurity and examining spatial variations across geographic/administrative divisions; De Silva (2007) using secondary aggregate data constructed indices of food insecurity and vulnerability in Sri Lanka at District level, focusing on four dimensions: food availability, 
affordability \& accessibility, health \& nutrition and another dimension termed 'other'. Using these indices the Districts were ranked by the intensity of food insecurity and vulnerability. Wickramasinghe (2008) ranked Districts based on food insecurity and vulnerability indicators representing seven causal dimensions of food insecurity and vulnerability: food availability based on production, production instability due to drought and war, market integration and food distribution, vulnerability to food affordability, accessibility and coping capacities. The WFP (World Food Program 2002, 2006) classified Divisional Secretariats (sub administration level below District level) using indices on vulnerability to food insecurity, constructed using aggregate data on availability, access and utilization of food. These studies are based on the premise that food insecurity is a multidimensional concept and hence focus on determinants of food insecurity and vulnerability within the broad groups of food availability, access to food, utilization and vulnerability.

\subsection{Selected literature on estimation of prevalence of food insecurity}

Sukhatme (1961) (cited in Naiken (2003)) estimated food insecurity using food energy intake as the indicator of food insecurity ${ }^{3}$, and defined food insecurity as food energy intake falling below a minimum required level. Considering that the energy requirement of an individual depends on age, sex, body weight, physical activity status and also by the body's efficiency of energy utilization, Sukatme proposed using a bivariate probability density $f(x, r)$ of energy intake $(x)$ and requirement $(r)$ and estimating the proportion of individuals $\mathrm{P}(\mathrm{U})$ with intake below requirement $r$, by:

$$
\mathrm{P}(\mathrm{U})=\mathrm{P}(\mathrm{x}<r)=\iint_{\mathrm{x}<r} \mathrm{f}(\mathrm{x}, \mathrm{r}) \mathrm{dxdr}
$$

Although the actual food energy intake ( $\mathrm{x}$ ) of each individual can be measured using information on food consumption, the actual individual requirement of food energy (r) is unknown because it depends on the individual's biological factors (age, sex, body weight, activity and the ability of the individuals body to utilize food). Therefore, information on the joint density $f(x, r)$ cannot be obtained empirically. But, hypothetically, within a group of individuals with the same biological factors, whose minimum dietary energy requirement is $r_{L}$ the proportion of people not satisfying the minimum energy requirement is given by:

$$
\mathrm{P}(\mathrm{U})=\mathrm{P}\left(\mathrm{x}<\mathrm{r}_{\mathrm{L}}\right)=\int_{\mathrm{x}<\mathrm{r}_{\mathrm{L}}} \mathrm{f}(\mathrm{x}) \mathrm{dx}
$$

where $f(x)$ is the density function of dietary energy intake, and $r_{L}$ is a cut-off point reflecting the minimum dietary energy requirement.

Naiken (2003) taking note of the uni-modal nature, short lower tail and longer upper

\footnotetext{
${ }^{3}$ The method assumes that foods giving the dietary energy bring along with it proteins, fats and other nutrients as well (Naiken, 2003).
} 
tail of per capita dietary energy consumption distribution, used a lognormal distribution to represent the marginal density function. Naiken derived the cut-off point, minimum dietary energy requirement, by aggregating the age-sex specific energy requirements using the proportion of population within these groups as weights.

Smith et. al (2006) used a direct comparison of household energy consumption with the minimum energy requirement level, for each household. The household minimum energy requirement was derived taking into consideration energy requirement based on median reference body weights in the World Health Organization growth standards corresponding to each household member's age, sex and activity status. Based on household survey consumption data, each household whose energy intake was below the requirement was classified as undernourished. The prevalence of undernourished in the population was taken to be the ratio between total number of individuals classified as under nourished in the sample divided by the total number of individuals in the sample.

\section{Methodology}

We estimate the prevalence of food insecurity using the method used in Sibrian (2007) which has been built on the works of Sukhatme (1961) and Naiken (2003). This method takes into account the variations in dietary energy consumed within the population, due to biological factors and income factors, and measures, prevalence of food insecurity as the proportion of the population whose per capita minimum dietary energy requirement per day are unsatisfied. They assumed that the probability density function of per capita dietary energy consumption $f(x)$ follows a lognormal distribution and estimated proportion of food insecure $\mathrm{P}\left(\mathrm{x}<\mathrm{r}_{0}\right)$ as given in equation (3).

$$
\mathrm{P}\left(\mathrm{x}<\mathrm{r}_{0}\right)=\int_{\mathrm{x}<\mathrm{r}_{0}} \mathrm{f}(\mathrm{x}) \mathrm{dx}
$$

When $\mathrm{f}(\mathrm{x})$ is lognormal with parameters mean $\mu$ and variance $\sigma^{2}$,

$$
\begin{aligned}
& \mu=\log _{\mathrm{e}} \bar{x}-\sigma^{2} / 2 \\
& \sigma^{2}=\log _{\mathrm{e}}\left(\mathrm{CV}^{2}(\mathrm{x})+1\right)^{1 / 2}
\end{aligned}
$$

and the only information required to specify the distribution are the mean $\bar{x}$ which is the mean of $\mathrm{x}$ and CV ( $\mathrm{x}$ ) which is the coefficient of variation of $\mathrm{x}$. The household dietary energy intake is taken to vary by income and also by biological factors (age, sex, activity level, the later three being factors determining dietary energy requirement). Then,

$$
\mathrm{CV}^{2}(\mathrm{x})=\mathrm{CV}^{2}(\mathrm{xl} v)+\mathrm{CV}^{2}(\mathrm{xl} \eta)
$$

Where $\mathrm{CV}(\mathrm{xlv})$ is the coefficient of variation in dietary energy intake due to income (v) and $\mathrm{CV}(\mathrm{xl} \eta)$ is the coefficient of variation in dietary energy intake due to biological (age, sex, physical activity status) requirements . Sibrian and Naiken

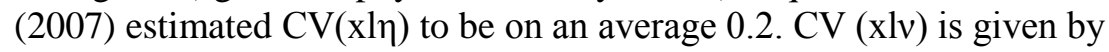




$$
\mathrm{CV}(\mathrm{xlv})=\sigma(\mathrm{xl} v) / \mu(\mathrm{x})
$$

where

$$
\begin{gathered}
\sigma^{2}(\mathrm{xl} v)=\left[\sum_{\mathrm{j}} \mathrm{f}_{\mathrm{j}}(\mathrm{xl} v)_{\mathrm{j}}{ }^{2}-\left\{\sum_{\mathrm{j}} \mathrm{f}_{\mathrm{j}}(\mathrm{xl} v)_{\mathrm{j}}{ }^{2}\right\} / \mathrm{n}\right] /(\mathrm{n}-1) \\
\mu(\mathrm{x})=\sum_{\mathrm{j}} \mathrm{f}_{\mathrm{j}}(\mathrm{xl} v)_{\mathrm{j}} / \mathrm{n}
\end{gathered}
$$

where $\mathrm{k}$ is the number of income classes, $\mathrm{f}_{\mathrm{j}}$ is the number of sampled households within the $\mathrm{j}^{\text {th }}$ income class, $(\mathrm{xl} v)_{\mathrm{j}}$ is the average dietary energy consumption per person per day of the $\mathrm{j}^{\text {th }}$ income class, and $\mathrm{n}$ is the total number of sampled households. Substitution in to equations (2) and (3) allow estimation of the parameters mean $\mu$ and variance $\sigma^{2}$, of the lognormal distribution, of dietary energy intake. By theory, the proportion of population $\left(\mathrm{P}(\mathrm{u})\right.$ ) below $\mathrm{r}_{0}$ (Minimum Recommended Dietary Energy requirement) is given by,

$$
\mathrm{P}(\mathrm{u})=\varphi\left[\log _{\mathrm{e}} \mathrm{r}_{0}-\mu\right] / \sigma
$$

Where $\varphi$ is the standard normal cumulative distribution.

We estimated the parameters of the lognormal distribution of per capita dietary energy consumption using household consumption data collected by HIES and food calorie information available in the literature (Department of Census and Statistics, Sri Lanka 2008a, Nanayakkara 1994). The frequency distributions of per capita dietary energy consumption (based on the collected HIES data) at District levels and at country level were uni-model with a short lower tail and a longer upper tail and Kolmogorov-Smirnov test and Shapiro-Wilk test for normality (Gujarati, 2003) performed on the logarithms of per capita dietary energy consumption confirmed normal distribution of the logarithms of per capita dietary energy consumption and hence confirming the appropriateness of assuming a lognormal distribution for per capita dietary energy consumption distributions at District and country levels.

The HIES collects information on household income, consumption, demographic and other socio-economic variables for a large sample of housing units throughout the country (Department of Census and Statistics, Sri Lanka 2008c, 2011). For food consumption the reference period is one week and quantity and value information for over 200 most consumed food items falling within 19 subgroups including cereals, processed food, vegetables, fish, meat, dairy products etc. are collected. In order to compare changes in food insecurity over time, we have estimated food insecurity prevalence using data from the 2006-2007 HIES and the 2009-2010 HIES.

In order to compare our food insecurity estimates with the FAO estimate (which is at national level) we used 1810 Kilo Calories (Kcal) per capita per day minimum dietary energy requirement (MDER) used by the FAO (FAO 2010), and also to compare our findings with the information available in the local literature, we used the $2030 \mathrm{KCal}$ per capita minimum requirement of dietary energy, used in the compilation of the official poverty line for Sri Lanka (Department of Census and Statistics, Sri Lanka 2004). 


\section{Results and Analysis}

Results show that at national level based on 1810 Kcal MDER, food insecurity prevalence is $18.7 \%$ in $2006 / 7$ and $18.9 \%$ in $2009 / 10$, and find to be very close to the national level food insecurity prevalence estimate for 2005-2007, 19\%, compiled by the FAO (FAO 2010). Based on an MDER of $2030 \mathrm{Kcal}$, i.e. at a higher level of cut-off point on the probability distribution, the magnitude of prevalence increases to $37.5 \%$ in 2006-2007 and 37\% in 2009-2010. The estimates for the Districts are shown in Table 1. In both survey periods, under both MDER levels, Nuwara Eliya District, had the lowest proportion of food insecure population; based on 2006-2007 data Gampaha District had the highest food insecure proportion but based on 2009-2010 data Colombo District had the highest food insecure population proportion. The results in Table 1 reveal a very important point: based on per capita dietary energy intake as the criterion for identifying the food insecure, the Western province consisting of Colombo, Gamapaha and Kalutara Districts, which is the most populated and most urbanized province in Sri Lanka also has the largest number of food insecure people.

Table 1: Food insecure population proportions (\%) at District level

\begin{tabular}{|l|c|c|c|c|}
\hline \multirow{3}{*}{ District } & \multicolumn{2}{|c|}{$2006-2007$ Data } & \multicolumn{2}{c|}{ 2009-2010 Data } \\
\cline { 2 - 5 } & $\begin{array}{c}\text { MDER 1810 } \\
\text { Kcal }\end{array}$ & $\begin{array}{c}\text { MDER } \\
2030 \text { Kcal }\end{array}$ & $\begin{array}{c}\text { MDER 1810 } \\
\text { Kcal. }\end{array}$ & $\begin{array}{c}\text { MDER } \\
\text { 2030 Kcal }\end{array}$ \\
\cline { 2 - 5 } & $\%$ & $\%$ & $\%$ & $\%$ \\
\hline Sri Lanka & 18.7 & 37.5 & 18.9 & 37.0 \\
\hline Colombo & 35.6 & 55.5 & 38.0 & 58.3 \\
\hline Gampaha & 37.7 & 57.9 & 34.0 & 54.8 \\
\hline Kalutara & 24.6 & 43.0 & 27.1 & 45.7 \\
\hline Kandy & 18.7 & 34.1 & 20.3 & 36.5 \\
\hline Matale & 23.0 & 38.9 & 22.7 & 38.5 \\
\hline Nuwara Eliya & 14.7 & 27.1 & 8.6 & 18.7 \\
\hline Galle & 29.6 & 47.6 & 30.5 & 49.3 \\
\hline Matara & 26.1 & 43.9 & 22.0 & 39.8 \\
\hline Hambantota & 16.7 & 30.6 & 17.0 & 30.0 \\
\hline Kurunegala & 22.3 & 37.8 & 21.1 & 36.2 \\
\hline Puttalam & 25.8 & 40.9 & 29.1 & 46.6 \\
\hline Anuradhapura & 20.8 & 35.2 & 20.1 & 36.3 \\
\hline Pollonnaruwa & 18.6 & 32.9 & 14.3 & 26.6 \\
\hline Badulla & 18.1 & 33.5 & 14.3 & 28.2 \\
\hline Moneragala & 16.7 & 30.6 & 11.2 & 22.1 \\
\hline Ratnapura & 21.1 & 36.5 & 20.2 & 35.2 \\
\hline Kegalle & 27.5 & 44.9 & 22.3 & 38.4 \\
\hline Batticaloe & 20.4 & 35.2 & 32.2 & 50.4 \\
\hline Ampara & 17.8 & 32.9 & 16.7 & 31.3 \\
\hline Trincomalee & n.a & n.a & 23.1 & 37.3 \\
\hline Jaffna & $\mathrm{n} . \mathrm{a}$ & $\mathrm{n} . \mathrm{a}$ & 14.1 & 26.1 \\
\hline Vavuniya & $\mathrm{n} . \mathrm{a}$ & $\mathrm{n} . \mathrm{a}$ & 10.0 & 20.8 \\
\hline
\end{tabular}

${ }^{4}$ n.a. : Survey data not available 
At national level irrespective of the MDER we use, between 2006-2007 and 20092010 the change in prevalence of food insecurity are negligibly small; at District level the changes are mixed. Based on both $1810 \mathrm{Kcal}$ MDER and $2030 \mathrm{Kcal}$ MDER, out of 19 Districts compared, in 7 Districts prevalence of food insecurity has increased, with the largest increase (15 percentage points) seen in Batticaloa; in the other Districts the increases range between 0.9 to 3.3 percentage points. Twelve Districts show decreases in food insecurity between 2006-2007 and 2009-2010, with the largest improvements seen in Nuwara Eliya, Badulla, Moneragala and Polonnaruwa. As implied by the methodology, the magnitude of the food insecurity prevalence estimates change with the MDER used as the cut off point, with the spatial pattern in food insecurity being unaffected. Therefore, in the analysis which follows, we use MDER as 1810 Kcals.

\subsection{Comparison with District average energy intake estimates}

At District level, in the absence of other food insecurity prevalence estimates to compare with, we correlated the District ranking based on food insecurity prevalence estimates with the District ranking based on estimates of District level per capita calorie intake reported in the HIES 2006-2007 survey report (Department of Census and Statistics, Sri Lanka 2008c) and HIES 2009-2010 survey report (Department of Census and Statistics, Sri Lanka 2011). The District rankings based on prevalence of food insecurity are well correlated to the District rankings based on District average per capita per day calorie consumption with spearman rank correlation coefficients (Gujarati, 2003) between -0.88 and -0.92 indicating a strong negative relation between District average calorie intake and prevalence of food insecurity.

\subsection{Comparison with findings from composite indices}

The correlations between District rankings based on prevalence of food insecurity and the District rankings based on food insecurity vulnerability indices constructed by De Silva (2007) and Wickramasinghe (2008) were compared to examine how well the food insecurity indications complemented each other. The Spearman rank correlations between the District ranks based on the estimated prevalence of food insecurity (based on 2006-2007 HIES data) and the food insecurity vulnerability ranking of Districts based on food availability (De Silva, 2007) was 0.55, correlation with ranking based on food affordability and accessibility was 0.57 .

The correlation between District ranking based food insecurity estimates (based on 2006-2007 HIES data) and the food insecurity and vulnerability ranking of Districts based on food production (Wickramasinghe, 2008) was 0.54 , correlation with ranking based on market integration and food distribution was 0.65 , correlation with ranking based on food affordability 0.56 and correlation with ranking based on food accessibility, 0.65 .

Correlation estimates coming from both studies show that the District food insecurity vulnerability rankings based on food availability, affordability, accessibility are moderately correlated with the prevalence of food insecurity, but 
move in the same direction. Therefore food insecurity prevalence estimates complement food insecurity and vulnerability estimates based on composite indices and can be used to strengthen spatial as well as temporal comparisons.

\subsection{Food insecurity and poverty}

Comparing ranking of Districts based on prevalence of food insecurity, and rankings based on official poverty estimates of the DCS (Department of Census and Statistics, Sri Lanka 2008c, 2011), contrary to our expectations that poverty and food insecurity should move in the same direction, Figures 1 and 2 shows that Districts with lower levels of expenditure poverty (Department of Census and Statistics, Sri Lanka 2008c, 2011, 204) having higher prevalence of food insecurity and vice versa. The Districts Colombo, Gampaha and Kalutara which have low poverty levels show high food insecurity, while Nuwara Eliya, Moneragala, Badulla which have high poverty levels show low food insecurity. High food insecurity in Districts with low levels of poverty may be resulting from low expenditure on food, and more particularly low expenditure on energy yielding staples, despite higher levels of total expenditure on food and non-food, which qualifies a household to be above the poverty line.

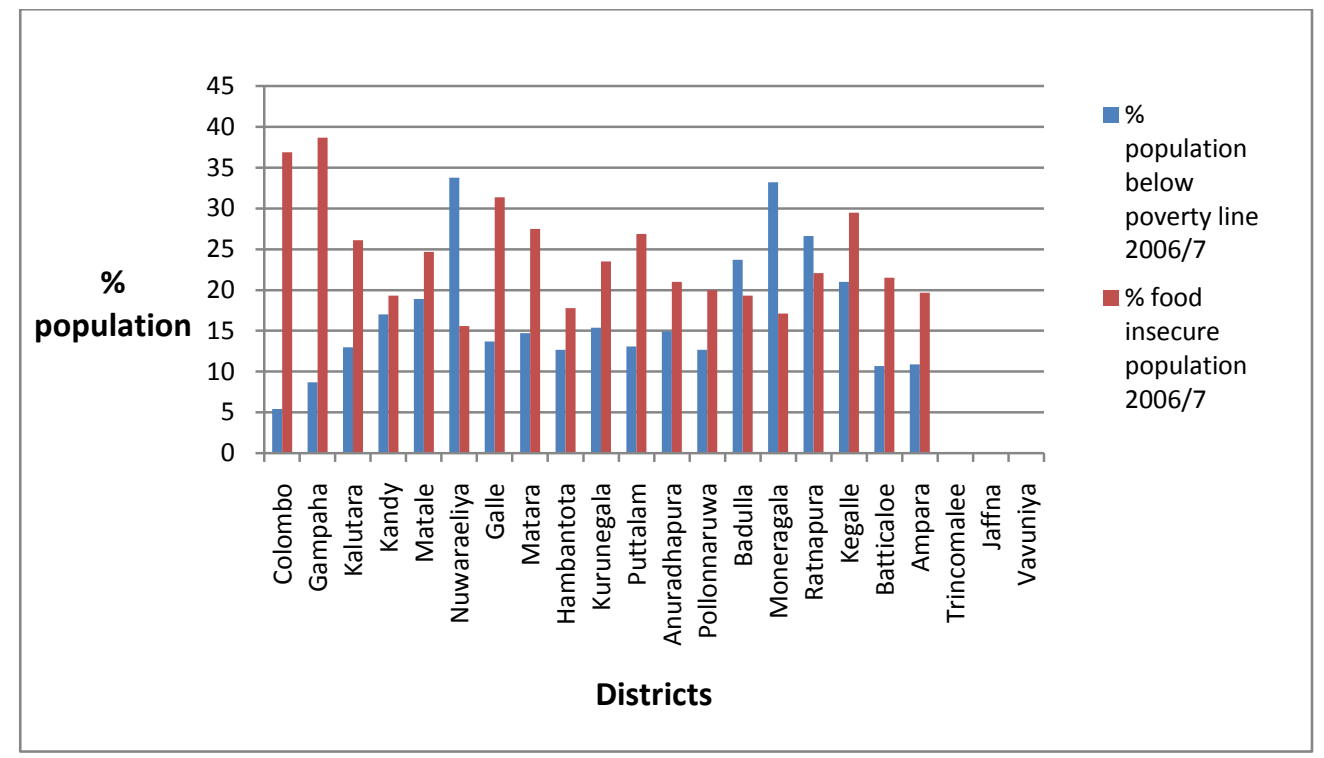

Figure 1: Poor and food insecure populations based on 2006-2007 HIES data

Table 2 shows that in the Districts where prevalence of food insecurity is high (e.g. Colombo, Gampaha and Kalutara) the food ratios ${ }^{5}$ as well as share of energy from staples are low compared to the Districts where prevalence of food insecurity is low (e.g. Nuwara Eliya, Moneragala). The ranking of Districts based on prevalence of food insecurity are negatively correlated to ranking of Districts based on food ratios,

${ }^{5}$ Share of expenditure on food to total consumption expenditure averaged over all sampled households in the District. 
-0.52 in $2006-2007$ and -0.33 in $2009 / 10$, and also negatively correlated the ranking of Districts based on share of energy from staples, -0.61 in 2006-2007 and -0.58 in 2009-2010, confirming that high food insecurity where level of expenditure poverty is low is likely to be a result of spending less on food compared to the spending on non-food, and also spending less on energy yielding 0staples.

For nutrition outcomes we consider at District level, the percentages of children under 5year who are stunted, under weight for height, and adult women whose body mass index is below the norm, given in DCS ((Department of Census and Statistics, Sri Lanka 2008b). Contrary to our expectations, we find low nutrition out comes in Districts with less food insecure population (Figure 3).

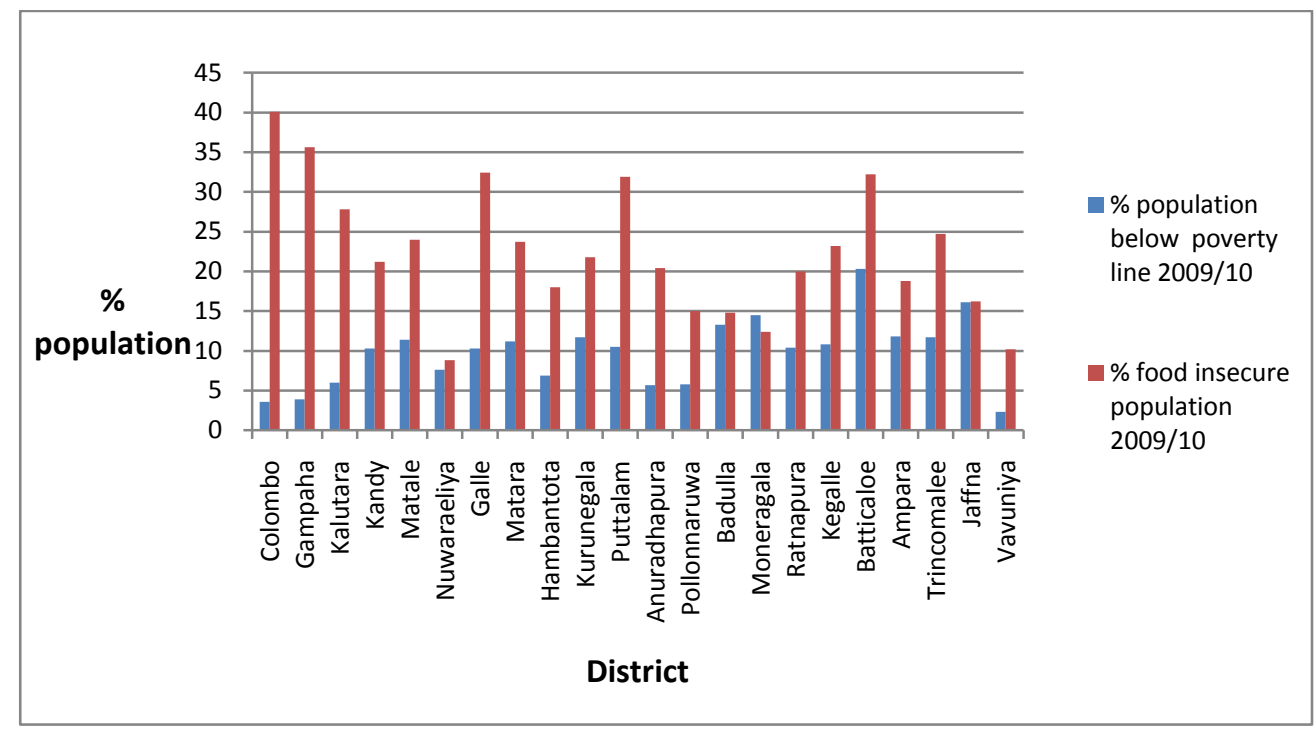

Figure 2: Poor and food insecure populations based on 2009-2010 HIES data

Table 4: Food ratios and share of energy from staples in diet.

\begin{tabular}{|c|c|c|c|c|}
\hline \multirow{2}{*}{ Districts } & \multicolumn{2}{|c|}{ Food Ratio $[24,25]$} & \multicolumn{2}{c|}{ Share of energy from staples } \\
\cline { 2 - 5 } & Based on & Based on & Based on & Based on \\
& $\begin{array}{c}2006-2007 \\
\text { HIES data }\end{array}$ & $\begin{array}{c}2009-2010 \\
\text { HIES data }\end{array}$ & $\begin{array}{c}\text { 2006-2007 } \\
\text { HIES data }\end{array}$ & $\begin{array}{c}\text { HIES data } \\
\text { HIES }\end{array}$ \\
\hline Colombo & 0.29 & 0.34 & 0.54 & 0.55 \\
\hline Gampaha & 0.33 & 0.35 & 0.55 & 0.54 \\
\hline Kalutara & 0.38 & 0.39 & 0.57 & 0.57 \\
\hline Kandy & 0.40 & 0.43 & 0.59 & 0.60 \\
\hline Matale & 0.38 & 0.44 & 0.6 & 0.60 \\
\hline Nuwara Eliya & 0.54 & 0.49 & 0.65 & 0.65 \\
\hline Galle & 0.39 & 0.46 & 0.57 & 0.57 \\
\hline Matara & 0.39 & 0.43 & 0.59 & 0.60 \\
\hline Hambantota & 0.40 & 0.42 & 0.6 & 0.60 \\
\hline Kurunegala & 0.41 & 0.46 & 0.59 & 0.58 \\
\hline Puttalam & 0.43 & 0.49 & 0.55 & 0.56 \\
\hline Anuradhapura & 0.36 & 0.40 & 0.58 & 0.59 \\
\hline
\end{tabular}




\begin{tabular}{|c|c|c|c|c|}
\hline Pollonnaruwa & 0.35 & 0.42 & 0.61 & 0.61 \\
\hline Badulla & 0.41 & 0.44 & 0.65 & 0.65 \\
\hline Moneragala & 0.52 & 0.54 & 0.64 & 0.63 \\
\hline Ratnapura & 0.44 & 0.46 & 0.64 & 0.64 \\
\hline Kegalle & 0.47 & 0.47 & 0.6 & 0.61 \\
\hline Batticaloe & 0.49 & 0.59 & 0.57 & 0.59 \\
\hline Ampara & 0.46 & 0.56 & 0.55 & 0.57 \\
\hline Trincomalee & n.a & 0.58 & n.a & 0.57 \\
\hline Jaffna & n.a & 0.65 & n.a & 0.59 \\
\hline Vavuniya & n.a & 0.46 & n.a & 0.56 \\
\hline
\end{tabular}

Analyzing the share of energy from staples (rice, rice based products, wheat flour, wheat flour based products, yams), we find that the Districts in which the average share of energy from staples are high, populations with poor nutrition outcomes are also high. Correlating the District ranks based on share of energy from staples and ranks based on nutrition outcomes, based on 2006-2007 data, we find moderate correlation of 0.48 indicating that, larger the share of energy from staples in the diet larger are the populations with poor nutritional outcomes.

\subsection{Food insecurity and nutrition outcomes}

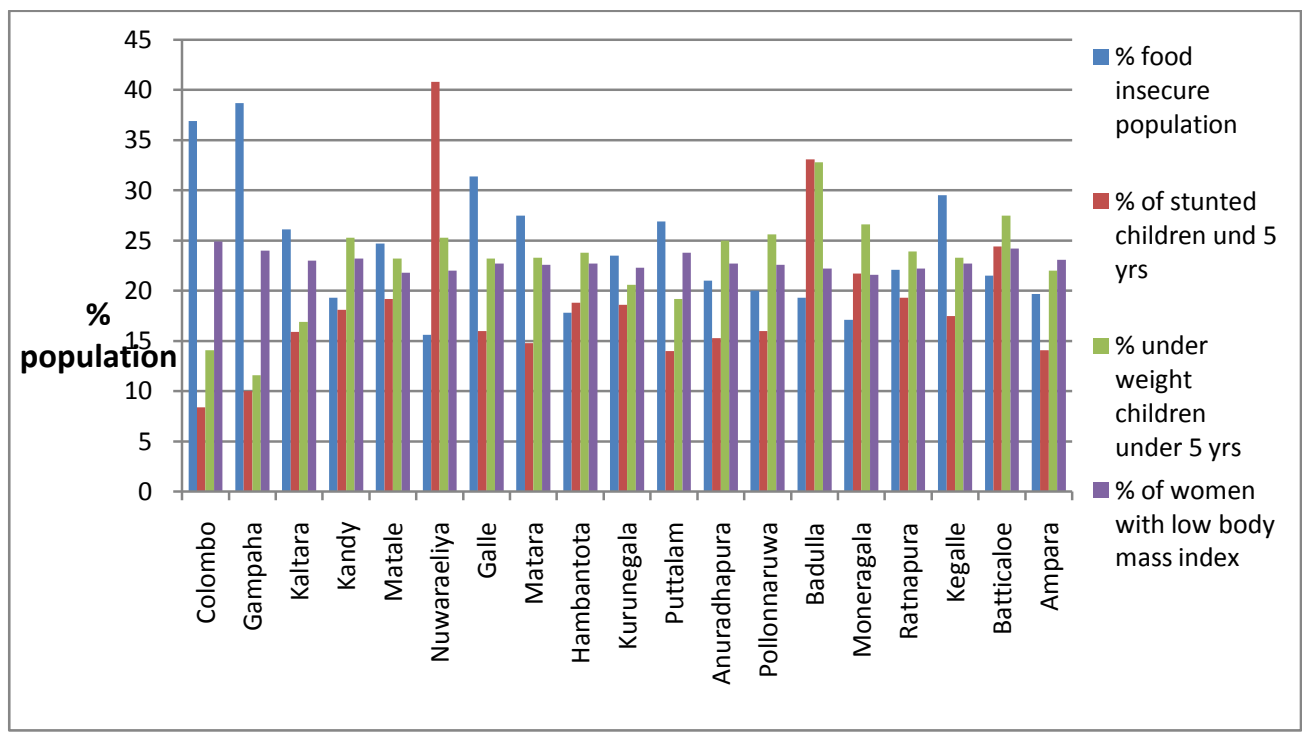

Figure 3: Food insecurity and Nutrition Outcomes

Given that staples are high energy sources compared to non-staples, the analysis indicates that Districts with a higher share of energy from staples in the diet, result low nutrition outcomes. This point out the necessity to re-think the assumption (which was based on literature (Naiken 2003, Nanayakkara and Premaratne 1987) 'food giving dietary energy bring along with it the protein and other nutrients'. This observation indicates the potential to improve the food insecurity measure, by 
accommodating other nutrient concerns in the estimation of prevalence of food insecurity.

\section{Conclusions and Recommendations}

In line with the literature an individual was defined food insecure if the food energy intake fell below a nutritionally recommended minimum level. Applying a method available in the international literature to nationally and periodically ${ }^{6}$ available HIES data food insecure population proportions were estimated for two time periods 2006-2007 and 2009-2010. Based on 2006-2007 data and under both MDER levels (1810 Kcal and $2030 \mathrm{Kcal})$, Nuwara Eliya District turned out to be the least food insecure and Gampaha District the highest food insecure; by 20092010 Colombo turned out to be the most food insecure District, while Nuwara Eliya remained least food insecure. The results point out that, based on per capita food energy intake for identification of food insecure populations, the western province (consisting of Colombo, Gampaha and Kalutara Districts) which is also the most populated and urbanized province in the country contains the largest number of food insecure individuals - an important matter to be considered in food policy formulation.

In Sri Lanka previous studies of food insecurity based on composite indices allowed relative comparisons of food insecurity between regions and across time but did not allow the estimation of proportions or counts of food insecure populations and hence it was not possible to know the magnitude of the food insecure populations and changes over time, limiting formulation of food security focused policies and interventions at regional level and more importantly the monitoring and evaluation of impacts of food security interventions. Further the observation that District food insecurity rankings based on composite indices being only moderately but positively correlated with the ranking based on food insecurity prevalence estimates; indicate the need for reconsidering the choice of variables used in constructing composite indices.

High food security but poor nutrition outcomes in Districts where official estimates of expenditure poverty are high reveal the play of low cost high energy staples in the diets of the poor, indicating the likelihood of imbalanced nutrition intakes, which is an important point to be considered in food policy. Also in Districts with low poverty but high food insecurity, especially in urbanized Districts, indications are that despite high levels of total consumption expenditure which made households to be above the official poverty line, less has been spent on food and also less has been spent on energy yielding staples, indicating nutritionally unbalanced diets which is again an important point to be considered in food policy. In terms of methodology, these observations suggest re-thinking the assumption: 'food giving dietary energy bring along with it the protein and other nutrients', and hence indicates the potential to improve the food insecurity measure, by accommodating other nutrient concerns in the threshold level for identifying the food insecure.

\footnotetext{
${ }^{6}$ HIES is conducted every four years.
} 
Therefore these food insecurity prevalence estimates can be used for both spatial and inter temporal comparisons, and the estimation methodology can be used to estimate the magnitude of food insecure populations for sub regions thus facilitating formulation, monitoring and evaluation of food security focused policies and interventions.

\section{References}

1. Department of Census and Statistics (2004), Report on official poverty line, Colombo. Available at www.statistics.gov.lk

2. Department of Census and Statistics (2008a), Food Balance Sheet. Colombo.

3. Department of Census and Statistics (2008b), Demographic and Health Survey 2006/2007 Report, Colombo. Available at www.statistics.gov.lk.

4. Department of Census and Statistics (2008c), Household Income and Expenditure Survey 2006/2007 Report. Colombo.

5. Department of Census and Statistics (2011), Household Income and Expenditure Survey 2009/2010 Report, Colombo.

6. De Silva, R.P. (2007), Food Insecurity and Vulnerability Assessment for Sri Lanka. FIVIMS Secretariat, Colombo.

7. Food and Agriculture Organization (1983), World Food Security: a Reappraisal of the Concepts and Approaches. FAO, Rome.

8. Food and Agriculture Organization (1996), Rome Declaration on World Food Security and World Food Summit Plan of Action, FAO, Rome.

9. Food and Agriculture Organization (2002a). Measurement and assessment of food deprivation and under nutrition: Proceedings of the International Scientific Symposium, FAO, Rome. At http://www.fivims.net/EN/ISS.htm

10. Food and Agriculture Organization (2002b), State of Food Insecurity in the World 2002. Available at www.fao.org

11. Food and Agriculture Organization . (2009). Declaration of the World Summit on Food Security. 16-18 November 2009, Rome. At www.fao.org

12. Food and Agriculture Organization (2010), State of Food Insecurity in the World 2010. Available at www.fao.org

13. Food and Agriculture Organization . (2012). State of Food Insecurity in the World 2012. Available at www.fao.org.

14. Gujarati, D.N. (2003) Basic Econometrics. Second edition, Mc Graw-Hill, Singapore.

15. Naiken, L. (2003), FAO Methodology for Estimating the Prevalence of Undernourishment. In Part II: Methods for Measurement of Food Deprivation and Under nutrition Available at www.fao.org

16. Nanayakkara A.G.W and Premaratne H.A.G. (1987) Food Consumption and Nutritional Levels. In Korale R.M.B. (Ed) Income Distribution and Poverty in Sri Lanka, Department of Census and Statistics, Colombo.

17. Nanayakkara A.G.W (1994) An analysis of poverty in Sri Lanka. Sri Lanka Journal of Social Sciences Vol 17, pp 49-78. 
18. Ravallion, Martin 2011. On multidimensional indices of poverty. Policy Research Paper 5580. World Bank. Washington DC.

19. Saxena, N.C. (2008), Hunger Under-nutrition and Food Security in India. Working Paper 44. Chronic Poverty Research Centre, Indian Institute of Public Administration. Delhi. At http://r4d.dfid.gov.uk

20. Sibrian, R. (2007), Indicators on Food Deprivation and Income Deprivation at National and Sub-national levels: Methodological Issues, Paper presented at the Fourth International Conference on Agriculture Statistics, October 25, 2007, China. Available at http://www.stats.gov.cn/english/icas/papers/

21. Sibrian, R and Naiken L. (2007), On the induced distribution of human energy requirements. FAO statistics working paper series No. ESS/ESSA/0013e Available at http://www.fao.org/es/ess/faostat/foodsecurity/papers_en.htm

22. Smith, L.C., Alderman H., and Aduayom D. (2006), Food Insecurity in SubSaharan Africa, New Estimates from Household Expenditure Surveys, IFPRI Research Report No. 146, Washington D.C.

23. Sukhatme, P.V. (1961). The World Hunger and Future Needs in Food Supplies. Journal of the Royal Statistical Society. A (General) 124, 463-588, DOI: 10.2307/2342930.

24. Wickramasinghe, W. (2008), Sub-National Food Insecurity and Vulnerability Assessment for Policy Interventions in Sri Lanka: Vulnerability Matrix Approach, Hector Kobbekaduwa Agrarian Research and Training Institute, Colombo (Unpublished).

25. Wickramasinghe, W. (2009), Spatial Variation of Food Insecurity and Vulnerability Dimensions of Sri Lanka, Sri Lanka Journal of Agrarian Studies, Vol. 13, No. 1, Hector Kobbekaduwa Agrarian Research and Training Institute, Colombo, pp 1-12.

26. World Food Program (2002) Spatial distribution of food insecurity in Divisional Secretariat Divisions in Sri Lanka . World Food Program : Colombo.

27. World Food Program (2006) Relative vulnerability of Grama Niladari Divisions to Food Insecurity. World Food Program Office: Colombo 